\title{
ОСОБЕННОСТИ УПОТРЕБЛЕНИЯ МЕСТОИМЕНИЙ ДЛЯ ВЫРАЖЕНИЯ КОРРЕЛЯТНО-РЕЛЯТНОЙ СВЯЗИ В СЛОЖНОПОДЧИНЕННОМ ПРЕДЛОЖЕНИИ
}

\section{FEATURES OF USE OF PRONOUNDS FOR EXPRESSING CORRELATIVE-RELATIVE CONNECTION IN A COMPLICATED SENTENCE}

I. Velichko

Summary: The article examines syntactic nominative units - phrasal names, which are formed as part of complex sentences of the pronominal-correlative type. In sentences of this type, the connection between the parts is represented by the ratio of pronouns that are close in meaning, forming the «correlate - relat» block. The article presents the features of the use of pronouns in this block; substantiation, adjectivation, adverbialization of phrasal names; complication of the «correlate - relat» block with an interpositive substantivat (a number of substantivates), which is part of the pronominal-correlative block; the use of demonstrative, attributive, indefinite, negative pronouns and their combinations as a correlate.

Keywords: syntactic nomination, complex sentences of the pronominalcorrelative type, correlate, relat.

\author{
Величко Ирина Владимировна \\ К.филол.н., дочент, Филиал ГОУ ВО «Ставропольский \\ государственный педагогический институт» \\ 2. Железноводск \\ velichkoir@yandex.ru
}

Аннотация: В статье рассмотрены синтаксические номинативные единицы - фразовые наименования, которые образуются в составе сложноподчиненных предложений местоименно-соотносительного типа. В предложениях данного типа связь между частями представлена соотношением близких по своему значению местоимений, образующих блок «коррелят - релят». В статье представлены особенности употребления местоимений в данном блоке; субстантивация, адъективация, адвербиализация фразовых наименований; осложнение блока «коррелят - релят» интерпозитивным субстантиватом (рядом субстантиватов), входящим в состав местоименно-соотносительного блока; употребление в качестве коррелята указательных, определительных, неопределенных, отрицательных местоимений и их сочетаний.

Ключевые слова: синтаксическая номинация, сложноподчиненные предложения местоименно-соотносительного типа, коррелят, релят.
Я зык каждого народа представляет собой отражение картины мира, получившее специфическое речевое выражение. В процессе освоения предметного мира человек познает вещи и явления, устанавливает между ними связи и взаимозависимости и дает им наименования. Отношение языковых единиц к неязыковым реалиям, фактам, событиям, явлениям определяется как номинация. В разработку проблем номинации внесли значительный вклад такие представители современной лингвистической школы, как Д.Н. Ушаков, Л.В. Щерба, В.В. Виноградов, С.И. Ожегов, О.С. Ахманова, Н.М. Шанский, Д.Н. Шмелев, П.В. Чесноков, А.А. Буров и др.

В современной лингвистике оформился своеобразный подход к проблеме номинативных единиц. Наряду с узуальной номинативной единицей - словом - и окказиональной, способной выполнять номинативную функцию, - словосочетанием, стали выделяться предикативные единицы - части сложноподчиненного предложения, имеющие в своем составе коррелятнорелятный блок типа mom, кmo, mo, что и под. Это явление получило название фразовой или синтаксической номинации. Сохраняя предикативность, данные придаточные части выполняют роль «окказиональных сложных наименований» [3, с.191], восполняющих отсутствие устойчивых наименований или служащих для конкретизации высказывания. Подробно концепцию субстантивной синтаксической номинации в русском языке рассмотрел в своих работах профессор А.А. Буров [1; 2]. Ученый отмечает, что «область синтаксической номинации представляется сложным, многоуровневым образованием, которое выражается в русском языке, благодаря гибкости его синтактико-сочетаемостных и позиционно-дистрибутивных свойств, весьма многочисленными и неоднотипными синтаксическими единицами» [2, с.12-13]. К таким синтаксическим наименованиям можно отнести местоименно-субстантиватные синтаксические наименования и фразовые наименования, являющиеся предикативными, возникающими на основе корреляции в сложноподчиненном предложении и дающие развернутое наименование денотату. А.А. Буров рассматривает синтактическую номинацию как номинативный знак бинарной формы «носитель атрибутивного признака - атрибутивный признак» [1, с.196]. На бинарность состава сложноподчиненных предложений с местоименно-соотносительными словами как их основной признак указывает и М.В. Пузыренко, подчеркивая взаимосвязь и взаимообуслов- 
ленность частей: «Одна часть - модус - содержит ярко выраженную семантическую недостаточность, требующую завершенности, другая - диктум - зависит от нее». Средства связи в сложноподчиненных предложениях местоименно-соотносительного типа в современной лингвистике определяются по-разному: двухместные скрепы с прономинальным релятом, соотносительная пара, коррелятивная группа, коррелятивные слова, т.е. слова соотносительные и союзные. В сложноподчиненном предложении первый компонент может быть представлен местоимением, а второй - придаточной частью, которая связана с главной частью при помощи относительного местоимения. Местоимение в главной части предложения играет типологически принципиальную роль условного дейктического знака денотата, элемента, который наполняется содержанием за счет второго компонента описательного наименования.

Она измучена мечтой оставить в мире до скончания веков себя, свои желания, мысли, одолеть то, что называется смертью, то, что непременно настанет для каждого в свой срок и во что она не верит, не хочет верumb.

Включение придаточных предложений в описательную номинацию свидетельствует о способности синтаксических единиц выступать аналогами лексического обозначения и легко замещаться в предложении словом или словосочетанием.

Напрасно ты просто ушел, напрасно не обратил внимание, не вчувствовался в то, что произошло на твоих глазах между этим юношей и этой девушкой, которую ты считал своей судьбой.

И трансформированное:

...не вчувствовался в происиедшее на твоих глазах между этим юношей и этой девушкой, которую ты считал своей судьбой.

В то же время нужно отметить, что не каждое фразовое наименование можно заменить лексическим, так как фразовое наименование позволяет наиболее полно и точно выразить авторские интенции. Ю.Г. Завьялова отмечает, что формирование синтаксического поля ФН решает несколько прагматических задач:

- введение информации;

- разворачивание темы высказывания в дискурсе;

- эмотивная оценка;

- формирование коммуникативной единицы.

Фразовая номинация возникает в тексте сложноподчиненного предложения местоименно-соотносительного типа, в которых связь между предикативными частями осуществляется при помощи соотношения близких по своим значениям местоимений: соотносительных в главной части и относительных в придаточной части, которые образуют блок «коррелят - релят»: $\mathrm{mom}$ - кто, то - что, такой - какой, таков - каков, так - как, столько - сколько, настолько - насколько. В данном случае придаточное предложение с его относительным местоимением прикрепляется непосредственно к соотносительному местоимению в главной части и наполняет ее своим содержанием. Так как соотносительные слова в сложноподчиненных предложениях местоименно-соотносительного типа сохраняют категориальные значения различных частей речи и соответствующие формы, наполняя эти местоимения своим содержанием, придаточные части как бы выступают в роли существительных, прилагательных, качественных и количественных наречий, т.е. как бы субстантивируются, адъективируются, адвербиализируются, например:

«И у тех, кто уезжал, было так тяжело и смутно, и больно на душе, будто ворон когтил им душу» (А. Фадеев) - (субстантивация).

«Одним словом, Варя представляла себе будущие отношения к Мечику такими, какими они были бы ей приятны, и старалась не думать о том, что действительно могло бы случиться, но доставило бы ей огорчение» (А. Фадеев) - (адъективация).

«Олег обнимал мать своими большими, сильными руками, а глаза его из-под широких бровей сияли так, как они сияли матери все эти шестнадцать с половиной лет, - чистым и ясным сыновьим светом» (А. Фадеев) (адвербиализация).

"Да, никакому человеку в истории не выпадало столько, сколько выпало нам на плечи, а видишь, не согнулись» (А. Фадеев) - (адвербиализация).

Исследования показывают, что, в отличие от адъективных и адвербиальных фразовых наименований, субстантивные фразовые наименования употребляются значительно чаще и являются более гибкими в функциональном отношении.

Коррелятивная связь частей сложноподчиненного предложения может быть осложнена интерпозитивным субстантиватом (рядом субстантиватов), входящим в состав местоименно-соотносительного блока:

«Левинсон хотел было назвать одним словом то единственное, что оставалось им, но, видно, слово было настолько трудным, что не смог его выговорить» (А. Фадеев).

«Вот это да!» - чуть не воскликнул он, сразу весь распахнувшись, обрадовавшись этому всему - живому, яркому и бедному, что двигалось, дышало и светило вокруг, и трепетало в нем» (А. Фадеев).

«Чем дальше они шли, Валько и Матвей Костиевич, тем все дальше и дальше отходило от них все то личное, даже самое важное и дорогое, что подспудно так трогало и волновало их до самой последней минуты и не хотело отпускать из жизни» (А. Фадеев).

Включение интерпозитивных субстантиватов ком- 
пенсирует отсутствие точного (адекватного) наименования и позволяет зафиксировать неясное, неточное восприятие предметов, явлений, их признаков, которое конкретизируется, получает смысловое наполнение в придаточной части сложноподчиненного предложения. Качественно-оценочные и экспрессивно окрашенные субстантиваты одновременно и служат номинации, и выражают авторское отношение говорящего к называемому.

Придаточная часть сложноподчиненного предложения может пояснять местоименно-субстантиватное синтаксическое наименование, и повтор коррелята в главной части усиливает поясняющую функцию субстантивной составляющей фразовой номинации:

«Oт белых стен, не имевших ни одного пятна, и высоких потолков веяло холодной отчужденностью, поль были всегда слишком блестящи и чисты, воздух слишком ровен, - в самых даже чистых домах воздух всегда пахнет чем-то особенным, тем, что принадлежит этому дому и этим людям» (Л. Андреев).

В некоторых случаях повтор коррелята в главной части сложноподчиненного предложения усиливает адъективную составляющую местоименно-субстантиватного синтаксического наименования:

«Точно уже все заранее знали, что так это со мной будет, точно внезапное сумасшествие вполне здорового человека в их глазах кажется чем-то естественным, маким, чего можно всегда ожидать» (Л. Андреев).

Наряду с указательными местоимениями в составе блока «коррелят - релят» в качестве соотносительного местоимения могут быть употреблены и определительные, и отрицательные, и неопределенные местоимения.

«А Сережку занимала больше внешняя практическая сторона дела: острые глаза его схватывали все, что попадало в поле их зрения из окна на чердаке, и $\mathrm{Ce}$ режка, сам того не замечая, запоминал каждую мелочь» (А. Фадеев) (определительное местоимение).

«Последнее время госпиталь занимал одно из отделений краснодонской больницы и теперь эвакуировался, но за недостатком транспорта всем, кто мог ходить, предложено было идти пешком, и еще более ста тяжелораненых осталось в Краснодоне без всякой надежды выбраться» (А. Фадеев) (определительное местоимение).

«Их выводили и сбрасывали в шурф по одному. И каждый, кто мог, успевал сказать те несколько слов, какие он хотел оставить миру» (А. Фадеев) (определительное местоимение).

«Ей все казалось, что пока она лежит здесь, к Вале уже пришли немцы и забирают ее и нет никого, кто мог бы сказать бедной Вале доброе и мужественное слово» (А. Фадеев) (отрицательное местоимение).

«Прячась от кого-то, кто по пятам крался за мной и заглядывал через плечо, я пробирался в конец сада, где на высоком валу стоял плетень, а за плетнем далеко вниз разбегались поля, леса и скрытые мраком поселки» (Л. Андреев) (неопределенное местоимение).

«Ему не нравилось место, на котором он ежедневно спокойно стоял в течение десятка годов: хотелось тоже делать что-нибудь такое праздничное, что делают другие» (Л. Андреев) (неопределенное местоимение, осложненное определением).

Употребление отрицательных, неопределенных, определительных местоимений в качестве коррелята позволяет расширить номинационное поле фразовой номинации за счет дополнительных значений отрицания, неопределенности, обобщения, привносимых местоимениями данных разрядов.

В художественном тексте можно встретить корреляты, выраженные сразу двумя местоимениями: определительным все и указательным то. Помимо обобщения определительное местоимение усиливает акцент на том, о чем говорится в придаточной части, и в целом на всем фразовом наименовании.

«A все то, что они делали в местах, где они проходили, это не интересовало генерала фон Венцеля, как не интересовало его то, что он живет в доме бабушки Веры и Елены Николаевны» (А. Фадеев).

В разговорной и литературно-художественной речи для обозначения лица вместо блока «тот - кто» Встречается употребление блока «тот - что»:

«- А ты по-миколашкину не меряй! - кричал сутулый и одноглазый, mom, что рассказывал о японцах» (А. Фадеев).

«- Слабо, ваше благородие, слабо, - отозвался mom, что в черной nanaxe» (А. Фадеев).

Рассмотренные способы осуществления коррелятно-релятной связи в сложноподчиненном предложении указывают на многообразие возможностей выражения синтаксической номинации в русском языке.

\section{ЛИТЕРАТУРА}

1. Буров А.А. Субстантивная синтаксическая номинация в русском языке / Под ред. д-ра филол. наук проф. К.Э. Штайн. = Ставрополь - Пятигорск: издательство Ставропольского государственного университета, 2012. - 400 с.

2. Буров А.А. Синтаксические аспекты субстантивной номинации в современном русском языке. Монография. В 3-х частях. Издание переработанное и исправленное. - Пятигорск: Изд. ПГЛУ, 1999. 
3. Мигирин В.Н. Язык как система категорий отображения. - Кишинев: Штиинца, 1973.

4. Пузыренко М.В. Соотносительное слово «Т0» В структуре сложноподчиненных предложений: коммуникативно-функциональный аспект (на материале современной прозы) http://www.vestnik.vsu.ru/pdf/lingvo/2015/04/2015-04-15.pdf

5. Завьялова Ю.Г. Механизм возникновения фразовой номинации как средства синтаксического описания https://readera.org/mehanizm-vozniknovenijafrazovoj-nominacii-kak-sredstva-sintaksicheskogo-140226266

( ) Величко Ирина Владимировна (velichkoir@yandex.ru).

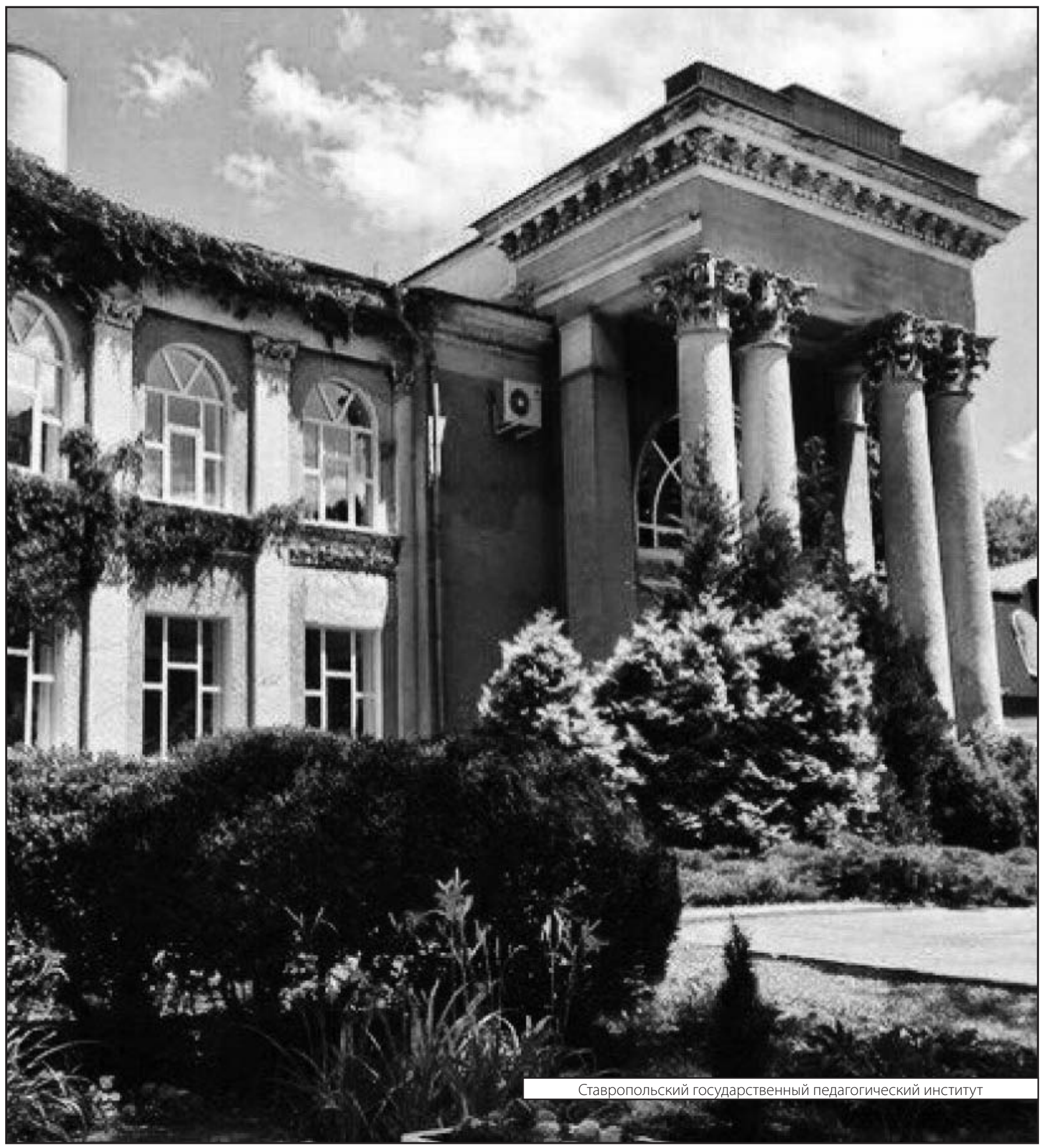

